\title{
The Restructuring of Spatial Scale and the New Global Geography of Uneven Development
}

\section{Neil Smith}

In The Long Twentieth Century, Giovanni Arrighi makes a convincing case that the period since the early 1970s marks a vital transformational crisis in world capitalism. This observation is of course not new but what is especially convincing about Arrighi's argument is the way he weaves a long historical schema of capitalist development into Marx's theory of finance capital, capital accumulation and crisis, and his unusual sensitivity to the spatiality of capitalist development. If the longer historical sequence of four "long centuries" of capitalist development from the fifteenth century is not always as convincing, his argument about the long twentieth century is. Dramatic industrialization of South and East Asia twinned with deindustrialization in Europe and North America in the 1970s marked the beginning of the crisis of a regime of capital that had dominated since the late nineteenth century. The "financial expansion" of the late 1970s and 1980s represented a response to that crisis and simultaneously a second stage of it, and although Arrighi does not extend the argument, we might add that so called globalization in the 1990s marks a third stage as different capitals seek to forge a new regime. He identifies an evolving territorial expansion of the arena under the sway of hegemonic capitals and an expanding geographical scale of dominance with each successive phase of capitalist dominance.

Arrighi provides one of the most geographically cognizant and sensitive analyses of the restructuring of the global economy since the 1970s, but I want to argue that even his analysis severely underestimates the central, substantive and itself changing role of geographical space in this history of the "long twentieth century." Arrighi argues - again as others have done - that the old divisions between First, Second and Third Worlds have been ruptured to the point of obsolescence, as new Asian states take a more dominant role in the constellation of global capitals, US economic leadership dims, and post-Cold war Russia and Eastern Europe struggle toward new capitalist ambitions. But I want to argue that this "crisis of transition" since the 1970s has been marked not simply by a geographical reshuffling of who occupies the core of the global capitalist system, or even by the rising of some national capitals at the expense of others. Rather, the entire geographical framework of capital accumulation is being transformed. In particular there is a restructuring of the geographical scales that organize and are organized by the production, circulation and reproduction of surplus value. This in turn constructs a whole new pattern of uneven geographical development in the global economy that affects local as much as global structures of social and economic production and reproduction.

I have previously proposed a theory of uneven geographical development under capitalism, but

1) Arrighi, G., The long twentieth century, Verso, 1994, 400p. 
the events of the 1980s and 1990s require an update of that argument. Much of the theoretical underpinning remains valid, I would argue, but the production of geographical scale, from the local to the global, consonant with globalization, indicates a much greater flexibility than previously imagined in the forms that capital accumulation can take. In particular, although the different geographical scales constructed as a framework of accumulation were conceived as mutable and not permanent, the apparent dispensibility of the nation state, as economic actor, however selective, marks a crucial evolution of global capitalism.

I will begin with a discussion of globalization, the ideology as much as the reality, and then move to a discussion of geographical scale. The third section will address the question of uneven development today in the light of globalization and new patterns of the production of scale.

\section{Globalization?}

In the rhetoric about globalization, the crucial question is: what exactly is being globalized. And as a corollary to this question, what is being ideologically veneered by the term "globalization"? In the first place, there is an important distinction between internationalization and globalization. But second, it is too simple to argue that "capital" is being globalized. Which capitals? Where? In what form?

A world market in commodity capital extraction and exchange was largely in place by the nineteenth century. It was assumed in Marx's critiques of capitalism, indeed even Adam Smith assumed something like a world market following the European discovery of the Americas. The market is not replete; significant interstices remain (even now) only tenuously connected. As regards finance capital, the rudiments of a global system were clearly in place by World WaráT, but it took the depression of the 1920s and 1930s and the postwar infrastructure of the IMF, World Bank and the Bretton Woods agreement of 1944 to make it a reality. The so-called Third World debt crisis of the early 1980s was a symptomatic result of the globalization of finance capital. So too was the dramatic spread of the economic crisis throughout Asia and Latin America after October 1997.

If global markets in commodity and finance capital were in place for the postwar expansion, the same cannot be so readily claimed about production capital, labor and cultural capital. The rise of multinational capital and the widespread international traffic in raw materials notwithstanding, it was not until the 1970s that production per se began to transcend the national boundaries that had previously bounded production systems and regimes into specific regions. On the one hand, the scale of competitive manufacturing in many sectors of the economy simply outgrew the national markets. Thus as Kevin Cox has argued "what is held to be the result of hypermobility of capital might simply be a change in the scale at which spatial divisions of labor are organized." On the other, component parts were more readily and more cheaply available from outside the pre-existing industrial regions. The "world car" of the early 1980s which, however dubiously, came to symbolize this shift to global production, actually stemmed from both scale and price

2) Smith, N., Uneven development: capital, nature, and the production space, Basil Blackwell, 1984, 198pp.

3) Cox, K., 'The politics of globalization: a sceptic's view', Political Geography 11, 1992, p.428. 
considerations. To the extent that it succeeded, "modernization" in the so-called Third World was precisely about seeding national economies, whether via growth pole politics or import substitution, or (more recently) via niche production for the global market. That the majority of commodities are still produced in local economies does not negate the acceleration of clearly globalized production.

The period since the late 1970th has witnessed an unparalleled global movement of labor, the wages of which are also a part of production capital. There have of course been numerous international migrations in the past, but there is no comparable period in which such labor fluidity touches the cultural economies of six continents. Far from coincidental, these labor movements contribute to economic globalization as new mixes of cheap or specialized labor facilitate expanded production in specific places, but they also just as clearly result from the social disruption brought about by that expansion. If the unprecedented mobility of labor lends credence to claims of a certain cultural globalization, it is important to remember too that the globalization of cultural capital is also tightly enmeshed with expanded communications technologies and therefore with the drive for economic accumulation.

Equally important are the connections between the economic and cultural dimensions of globalization on the one side and the neo-liberal politics of structural adjustment, privatization and deregulation on the other. Centred on the nation-state, a certain geographical congruence between economic and political activities characterized the development of capitalism from the eighteenth century through the postwar era. Globalization inaugurates the systematic recession of this geographical congruence as more and more capitals of a smaller and smaller size find it possible to "jump" the national boundaries that defined state territories. Indeed they find themselves required to jump scales for sake of competitive survival, and as a result national governments became less and less willing to regulate capital, for fear of capital flight. Here again economic and social globalization feed each other: the national governments of Europe and North America, under severe pressure from emerging as well as existing economic competitors by the late 1970s were less and less dependent on a home-grown, low-wage and reserve labor force that was most dependent on welfare and social services. The welfare states that had been erected earlier in the century, precisely as a means of both securing a labor force and preventing its revolt, could now be dismantled as the sources, costs and functions of social reproduction were also radically globalized. Privatization may have been an ideological commitment but it was also a desperate response to economic globalization by conservative governments. The crises provoked by privatization and wholesale social service cuts are the social face of the globalization of capital. All of this is quite explicit in the global vision of one ex-Assistant Secretary of the Treasury:

4) (1) Sassen, S., The mobility of labour and capital: a study in international investment and labor flow, University of Cambridge Press, 1988, 224p. (2) Appadurai, Modernity at large, University of Minnesota, 1996, 229p.

5) See for example, Katz, C., 'Textures of global change: eroding ecologies of childhood in New York and Sudan', Childhood 2, 1994, pp.103-110.

6) Martin, R., 'Fables of finance', Environment and Planning D: Society and Space, 1999 (forthcoming).

7) Ibid. 
In a global economy, capital will flow to areas where returns are highest and away from those where it is savaged by taxes, regulations and tort liabilities.... If the U.S., a welfare state grown soft and fat, is to survive in a competitive post-socialist world, it must privatize Social Security and health care; abolish welfare and cease to tax human and physical capital.

Two conclusions can be drawn from these arguments. In the first place, and most obviously, globalization represents a political and social as much as economic agenda. Third, insofar as globalization is seen to provoke space-time compression, peripheral industrialization, and capital flows to places of highest returns, it expresses a central tendency in the uneven development of capitalist economies. This tendency toward a geographical equalization of levels and condition of social production is a spatial corollary of Marx's theory of capital accumulation and the equalization of the profit rate. Recall Marx's remark that capital "exacts in every sphere of production equality in the conditions of the exploitation of labour"; that capital brings about an "annihilation of space by time"; or his anticipation at one point that India would develop to a level akin to that of capitalist Britain. While the expectation concerning India and other "backward" economics was dramatically misconceived insofar as Marx did not forsee the rigidity with which national and colonial boundaries would be defended against competitors - external and internal - the emergence of the newly industrializing countries since the 1970s also suggests that a deepseated if never unchallenged logic of equalization nonetheless operates, however partially.

But this attraction of some "underdeveloped" economies to the global lodestone of capital has been matched since the 1980s by a virtual expulsion of other economies, far more dramatic than even under the aegis of modernization. This expulsion has gone virtually unremarked, even if the consequent unprecedented destruction of everyday life has been fitfully recorded. From the Sahel famine of 1968-1974 to the Central African genocide that started in Rwanda (and to a lesser extent Burundi) in 1994 and spread to Zaire by 1997, sub-Saharan Africa has borne the brunt of what we as academics politely refer to as "globalization" or "global restructuring." Denied access to more than a trickle of capital on the global markets, yet condemned to resolve the local consequences of an earlier global adventurism by colonial powers, much of this region has experienced the message of modernization and globalization at its most cruelly satanic. The promise of prosperity in exchange for structural adjustment has brought the obverse of social development, the underbelly of globalization.

In retrospect, we can see the Sahel famine and the chronic famines in Ethiopia and Sudan lasting through the 1980s as announcing the beginning of a new episode in the history of sub-Saharan Africa. The brutal ghettoization of Sub-Saharan Africa in the global economy has many sides. It has been marked by the production and maintenance of extreme scarcities; sometimes vicious social struggles over access to place and power; the rigid crystallization of ethnic, class and regional

8) Capital vol. I , Internationál Publishers, 1967, p.397. For a development of this argument about equalization, see Smith, N., Uneven development: nature, capital and the production of space, Basil Blackwell, 1991 (2nd edn.), pp.113-119.

9) Smith, N., 'Satanic geographies of globalization', Public Culture 10, 1997, pp.169-187.

10) See the classic study by (1) Watts, M., Silent violence, University of California Press, 1983, 687p. and (2) Richard W. Franke, R. F., and Chasin, B. H., Seeds of famine: ecological destruction and the development dilenma in the West African Sahel, A1lanheld, 1980, 266p. 
identities; repressive and often corrupt postcolonial governments built on the exploitation of scarcity and backed by military power; and serious warfare in virtually every state in the last two decades. Nor do the most direct and densest connections into the global economy bring immunity; Nigeria and South Africa have in different ways been central to the penetration of capital into subSaharan Africa but the populations of both have paid dearly in the process.

In alluding to this litany of horror in the veritable ghetto of global capital, it is important that we maintain perspective. The temptation to see this mayhem as beyond comprehension and unprecedented in world history has not been avoided by right-wing apocalypts. Thus in a widely hyped article with book to follow, travel writer Robert Kaplan presents, from the vantage point of West Africa, "a portrait of the world as it is coming to be, a world where unprecedented social, political and environmental dysfunction constitutes the fabric of daily life."

The social chaos in much of the underdeveloped world is real but Kaplan's new environmental determinism propping up a righteous global survivalism is a cause not a solution. It has to be remembered that the most deadly war of the twentieth century involved primarily European "tribalism", at a cost of some 30 to 45 million lives; that a single US act of "primitivism" in Hiroshima killed an estimated 135,000 people (and that the US Congress succeeded in preventing even a public discussion of this genocide, via the Smithsonian Institution, in its fiftieth anniversary year): that the unprecedented ecocide in the Iraq desert was made in America; that the holocaust of Rwanda did not match the scale of Nazi genocide against Jews and communists, gays and travelling people; and that Slobodan Milosevic has re-performed genocide as ethnic cleansing under the banner of Serbian nationalism at century's end.

In this context, it makes sense to think of the recent history of sub-Saharan Africa in somewhat different terms. In fact, sub-Saharan Africa since decolonization has been treated to a crash-course in the most vicious aspects of free-market capitalism while being largely denied any of the benefits. For what is remarkable about the last two decades in this region is its virtual systematic expulsion from capitalism, the ideology of modernization notwithstanding. Thus in the early to mid-1980s, when "Third World debt" led the list of economic crises in the "Western" press, the utter silence concerning sub-Saharan debt revealed loudly that this region was too poor even to have the luxury of Latin American-level indebtedness. In the 1980s the 14 countries of sub-Saharan Africa (excluding West Africa and South Africa) amassed a mere $\$ 4.8$ billion in debt to the US. (By way of comparison, New York State had a budget deficit of nearly $\$ 5$ billion in its 1995-96 budget, and Harvard University has an endowment fund of $\$ 5.2$ billion.) Further, between 1990 and 1993, the total external debt increased by only $1.4 \%$ per year. As regards investment, private ventures in the whole continent of Africa fell by $25 \%$ in the 1980s and have fallen even further in the 1990s as capital has been diverted to some parts of Eastern Europe 1989 may have been a triumph for capitalism, by some accounts, but it was a death sentence for many in Africa. In the anemic

11) See (1) Murray, M. J., The revolution deferred. the painful birth of Post-Apartheid South Africa, Verso, 1994, 248p. On Nigeria, (2) Michael Watts documents the "shock of modernity" in Pred, A. and Watts, M. J., Reworking modernity. capitalisms and symbolic discontent, New Brunswick, Rutgers University Press, 1992, pp.21-63.

12) (1) Kaplan, R. D., 'Coming anarchy: how scarcity, crime, overpopulation, tribalism, and disease are rapidly destroying the social fabric of our planet', Atlantic Monthly February 1994, pp.44-76. (2) The ends of the Earth, Random House, 1996, $476 \mathrm{p}$. 
language of the New York Times, "the international business community has largely disappointed the development experts." Mali, to take just one example, is unable to attract capital to help finance a new power corporation even as US, Canadian and Australian companies fall over themselves to extract gold, diamonds and oil from the country. "Their hope," the report continues, "is for the kind of quick extraction of wealth that led to the continent's early disenchantment with capitalism." As part of the restructuring of the global economy in the 1980s and 1990s, sub-Saharan Africa has been unceremoniously redlined in the global financial markets.

This dramatic strategy of exclusion and ghettoization is not restricted to the private economy, nor indeed to Africa. At the beginning of the 1990s the British and French governments announced cuts in foreign aid to Africa, and in 1994 the U.S. Agency for International Development (AID) began closing missions in the poorest countries. AID is the principal U.S. agency charged with providing aid for foreign development projects: its total 1995 aid budget was $\$ 13.7$ billion; its pervasive reputation casts it as a political agency that disburses economic carrots for political purposes, and that shelters CIA operatives abroad. Since 1989 it has rechannelled large amounts of aid to Eastern Europe and in consequence, by 1993, has decided to cut operations in 21 countries in Africa, Asia and Latin America. These include some of the poorest countries in the world. Leading the list was sub-Saharan Africa: Burkina Faso, Botswana, Cameroon, Cape Verde, Chad, Cote d'Ivoire, Lesotho, Togo, and Zaire. The latter was singled out for its 30 year-long dictatorship (albeit U.S. supported) and for the fact that per capita income had fallen from $\$ 710$ to $\$ 210$ since 1977. Oman, Tunisia, Afghanistan, Thailand, the South Pacific Islands were also on the list, along with Pakistan which was explicitly singled out as an Islamic state that was developing an atomic capability. Belize, Chile, Costa Rica and Uruguay were also included. Only narrowly did USAID avoid complete abolition by Congress in 1995 which cited the organization's now-obsolete cold war political function.

By contrast, the World Bank and IMF have found since the early 1980s that they could bribe nearly $20 \%$ of the world's national economies to undergo "structural adjustment" programs of debt curtailment and market privatization. This led to any number of "IMF riots", as they came to be called, following an uprising in Kingston, Jamaica, aimed directly at the IMF austerity program. But it also led to worse. Since at least 1978, the World Bank has consistently funded multimillion dollar "development" projects in Rwanda, over the objections of anthropologists and others who warned explicitly that the projects established a patronage system for the dominant Hutus while reducing grazing areas and access to other resources for the Tutsis. Far from an unpredictable and inexplicable outburst of so-called tribal violence, Rwandan genocide was a partly predictable

13) (1) French, H. W., 'In Africa, West can pay now, or later," New York Times February 26, 1995. (2) 'A rescue for Africa', International Herald Tribune January 13-14, 1990. If West Africa, (especially Nigeria) is included along with South Africa, the figures for debt are much higher, but despite debt service, they are not increasing rapidly. See (3) The World Bank, World debt tables 1994-1995, Washington D.C., 1994, p.216. As one commentator has said, "You could write off all of Africa's [not just sub-Saharan Africa] debts tomorrow, and it wouldn't affect international financial markets" (Thomas Callaghy, quoted in French, 'Ín Africa', op. cit.)

14) (1) 'U.S. to close 21 Foreign Aid Missions', Washington Post November 20, 1993. (2) Steven greenhouse, 'It's a hard job saving foreign aid (but the job is still there)', New York Times February 19, 1995.

15) Walton, J., 'Urban protest and the global political economy', (Smith, M. P. and Feagin, J. R., eds., The capitalist city, Basil Blackwell, 1987), pp.364-86.

16) Ridgeway, J., 'Debt again', Village Voice August 9, 1994, p.11. 
outgrowth of specific strategies of globalization visited on the social conflicts that emerged from colonial and post-colonial administration.

Globalization, then, is only the latest stage of uneven development, succeeding the three-decade long postwar era. As such globalization appears as an increasingly pure form of imperialism. Quite different from the colony-led imperialism that ushered in the twentieth century, the globalization of culture and capital at the end of the century takes place not via the dictates of colonial administrations, colonial trade preferences, or even the imminent threat of military retribution for non-co-operation. The latter has not evaporated, of course, as Granada, Panama, Haiti, Lybia, Iraq and Serbia all found out in the last two decades of the century, but the in the case of the Iraq, the military strategy was a quite temporary means of ensuring adherence to a "New World Order." What was new, was the unprecedented extent to which imperial exploitation no longer emanated first and foremost from political and military control but rather resulted from the unfettered operation of the global market itself.

At the same time as accepting that globalization is more than simply a ruse by corporate economists and business school professors in search of a new rationalization of existing forms of exploitation - a real shift in the operation of global capitalism is underway - it would also be a mistake to follow these same pundits by assuming that globalization marks, for all intents and purposes, the end of geography. At the very least, this is the radically class-circumscribed and ethnocentric view from those who think themselves in the cockpit of globalization. Whatever the mix of complicit colonial legacy and economic redlining, postcolonial ineptness and venal global economic vision that has brought us to the present, these satanic geographies of postmodernization reveal at their core the grotesqueries of global capital. For against the perfectly evident tendency toward equalization of levels and conditions of production, there is an equally important countervailing tendency, traceable to the continuous division of labors and capitals, toward the geographical differentiation of global space. The global restructuring of the 1980s and 1990s embodies not just an evening out of social and economic development levels in some quarters but simultaneously a deepening and reorganization of existing patterns of uneven geographical development.

\section{The Production of Geographical Scale}

As the language of globalization itself suggests, much of the current restructuring involves a dramatic remaking of geographical scale. The most straightforward implication of this rhetoric is that an economy previously organized into different national units was now global. The scale question is of course much more complicated than this. The global scale was already well in place before the 1980s having crystalized throughout the century as the scale of capital circulation and the market. The national scale, a project of more than two centuries and many bourgeoisies, was largely in place by the beginning of the century but was completed with the decolonization of Asia

17) See for example, O'Brien, R., Global financial integration: the end of geography, Royal Institute of International Affairs and Council on Foreign Relations, 1992, 120p.

18) See 2) pp.99-113. 
and Africa between the late 1940s and the early 1990s. The nation state emerged as a fixed form via which to regulate economic competition in the market and the contradictory impulses of equalization and differentiation of levels and conditions of production. Nation states came into the world twinned with national capitals. Within them, relatively coherent and discreet regions emerged as the production platforms of national economies.

Cities, which have historically performed multiple functions ranging from the military and religious to the political and commercial (depending on the history and geography of their construction and transformation) were increasingly defined in the nineteenth and twentieth centuries according to their role in the organization of social reproduction - the provision and maintenance of a working class population. The city was also an extraordinary centralization of means of production and productive activity, cultural work and political strife - and much more - but as soon as the division of labor between social production and reproduction became simultaneously a spatial division, the scale of the modern city was defined in terms of the limits of the daily movement of workers between home and work. We could fill out this picture by conceptualizing the local community as the scale of physical reproduction, the home as the locus of biological reproduction, and the body as the scale at which identities are primarily crystalized.

The Keynesian city of postwar advanced capitalism in the West represented the zenith of this definitive relationship between the city and social reproduction. This is a consistent theme running through the work of major European American urban theorists of the last third of the century. The Keynesian city was in many respects the welfare hall for each national capital, combining the functions of social support and the reproduction of a national labor market. Indeed the so-called urban crisis of the late 1960s and 1970s was widely interpreted as a crisis of social reproduction, having to do with the dysfunctionality of racism and patriarchy and the contradiction, between an urban form elicited according to strict criteria of profitability yet one that had to justified in terms of the efficiency and efficacy of social reproduction. But by the 1970s the idea of separate "national economies" was obsolete. International linkages per se were not new, of course, but the level of economic integration across national boundaries was, and with commercial and financial capital largely globalized already, it remained only for production capital also to "jump scales". This was the real basis for the "discovery" of globalization by the late 1980s, a process that was dramatically fueled if not caused by the generalization of computer technology, the comparative cheapening of air transportation, and the parallel cheapening of most raw materials.

The erosion of the national scale, at least in economic terms, is having a direct and rapid impact on cities, and to understand how and why it is necessary to identify the different dimensions of the weakened national scale. First and most obviously, enhanced communications and deregulation have increased capital mobility and dramatically expanded the range of capitals that are free to move where lower costs of social reproduction in turn lower the costs of production. Second, unprecedented labor migration flows in the last quarter of the century have increasingly distanced local economies from automatic dependency on home grown labor. There may not yet be a single

19) See 2) pp.135-147. (1) Smith, N., 'Contours of a spatialized politics', Social Text 33, 1992, pp.54-81.

20) See (1) Lefebvre, H., La revolution urbaine, Paris, 1971, 186p. (2) Harvey, D., The urbanization of capital, Basil Blackwell, 1985, 239p. (3) Castells, M., The urban question, Edward Arnold, 1977, 502p. 
global labor market but there are many international labor markets all of which are globally interdependent. Third, forced into a more competitive mode vis-a-vis capital and labor, local states (including city governments) have offered carrots to capital and applied the stick to labor, they have become much more selective about the extent and level of subsidy for social reproduction since they can depend to a greater extent on imported labor whose costs of reproduction are bourne elsewhere. Fourth, the same pressures applied to the national state have led to a dramatic erosion of social capital provision at that scale also, intensifying the pressure on city governments to further sever their responsibilities for social reproduction. Finally, amidst the restructuring of production beginning in the 1970s and with class and race-based struggles broadly receding, city governments had an increased incentive to abandon that sector of the population surplused by both the restructuring of the economy and the gutting of social services. Comparatively low levels of struggle were crucial in the virtual non-response by government to the Los Angeles uprisings after 1992, a dramatic contrast with the response to the 1960s.

Two mutually reinforcing shifts have consequently restructured the functions and active roles of cities. In the first place, systems of production previously defined at the regional scale were less and less defined in terms of the needs of national capitals, contributing in the 1970s and 1980s to the rash of deindustrialization in regions from the Ruhr to the US Midwest while whole new regional ensembles of production emerged. Unlike the disintegrating industrial regions of Europe and North America that they replaced - and even when that replacement appeared to take place within the shells of the old regions - the new regions emerging in the late $20^{\text {th }}$ century are from the start defined in terms of the global market; they are first and foremost engines of global rather than national economies. Crucially, they also involve a significant shift in the established scale hierarchies and specifically in the scale at which the new production complexes are organized. Disappearing are the extensive manufacturing regions that might extend for hundreds of thousands of square kilometers and envelop numerous specialized urban manufacturing centers. In their place has come production regions that are little more than extended metropolitan centers, or regions strung between such centers. The metropolitan world comes to dominate the regional world rather than the other way round. Silicon Valley, Bangkok and Sao Paulo to a considerable extent succeed and supplant the American Northeast and the English North and Midlands. Thus on the one hand the restructured world economy is already remaking twenty-first century cities as leading platforms of global production.

But second, the corollary is also taking place. Confronting staccato economic crises between the early 1970s and the 1990s, punctuated by bouts of rapid market expansion, national states found themselves increasingly unhinged from the economies of their territories and, given the extent of capital and labor migration, no longer necessarily responsible for bearing the costs of social reproduction associated with the labor forces occupying the state's territory. In the United States, President Carter's attempted urban plan of 1978 represented the last time that an attempt was made to tie the economic fate of the country's cities so definitively to the national economy. The failure of that plan, which left the fiscal crisis of many older cities unresolved by federal

21) Castells, M., The rise of network society, Basil Blackwell, 1996, p.239. 
intervention gave the first intimation of an economy increasingly delinked from and independent of its cities, and the wholesale demise of liberal urban policy followed swiftly. Clinton's cynical slashing of the social welfare system 18 years later capped this demise and has to be understood as an entirely rationale (market-based) response to both globalization and the state's increasing independence from urban-based social reproduction.

That the economic rationale for nations states is significantly eroded on the cusp of the twentyfirst century is surely indisputable. Quintessential geographical constructs of modernity, nation states could well become, in Jurgen Habermas's felicitous phrase about modernity, dominant but dead. By the same token, a substitution of political and cultural for economic rationales may equally transform the role of nation states. But it is the consequent transformation of localities that interests us here. It is increasingly clear that in the vacuum created by the economic dissipation of the nation state is being replaced by an increasingly powerful and definitive nexus between the global and local scales. This shift is perhaps best captured in Erik Swyngedouw's awkward but very apt phrase, "glocalisation." Processes of globalization and localization of economic activity are inevitably intertwined, and analyses of global change that do not incorporate local restructuring miss the larger reconstruction of geographical scale that produces so-called globalization.

$\AA ̊ @$ Twenty-first century urbanism, then, seems destined to reappropriate the rationale enjoyed by cities in the earliest days of industrial capitalism in Europe, a time when, no incidentally, the economic authority of the nation state over cities was also weak. But the leaders in this combined restructuring of urban scale and function lie not in the old cities of advanced capitalism where the disintegration of traditional production-based regions and the increasing dislocation of social reproduction from the urban scale is partial, painful, and unlikely to pass unopposed. In many cities of Asia, Latin America and Africa, however, where the Keynesian welfare state was never fully installed, and the definitive link between the city and social reproduction was never paramount, the fetter of old forms, structures and landscapes will be much less. These metropolitan economies will operate as the new production platforms of a new globalism. Unlike the suburbanization of the postwar years in North America and Europe, dramatic urban expansion of the early twenty first century will again be led by the expansion of social production rather than reproduction. In this respect at least, Lefebvre's announcement of an urban revolution redefining the city and urban struggles in terms of social reproduction, or indeed Castells' definition of the urban in terms of collective consumption, will fade into historical memory.

In other words, if "capitalism shifted gears" with the advent of Keynesianism "from a 'supplyside' to a 'demand-side' urbanization," as Harvey once observed, twenty first century urbanism reverse this shiff. If in this Keynesian world the geographical sprawl of suburbs in western cities could potentially undermine the law of value insofar as the trade-off between lower house prices and higher-cost commutes destabilized the value of labor power - and thereby contributed to the

\footnotetext{
22) In 1975 the New York Daily News printed the apocryphal headline, following President Ford's 1975 refusal to subsidize the city: 'Ford to City: Drop Dead'.

23) Swyngedouw, E., Neither global nor local: "globalization" and the politics of scale', in Cox, K., ed. Space of globalization, Guilford Press, 1996, pp.137-166.

24) Above 20) (2) p.202 and p.209.
} 
formation of economic crises - the argument is increasingly transposed in the twenty first century city. The production of metropolitan space still potentially constrains the law of value except that it is more and more the environmentally inspired deterrence of production rather than social reproduction that will press against the law of value. Some of the constraint may be similar traffic jams and exorbitant rents - but with highly decentralized, interlinked production nodes nestled all around a metropolitan area rather than concentrated in industrial zones, the effects of these constraints are transformed. More broadly, the much acclaimed. Postindustrial city increasingly appears as a quixotically narrow vision in time and space. Given the present trajectory it will not take long for the opinion setters with access to the media to begin to ask how on earth we ever came to believe such a transparently self-serving fiction, and to begin to reveal the worlds of urban work that such ideologies erased.

This restructuring of scale and the rise of the "metropolitan world" represents just one thread of the new urbanism of the twenty first century. It dovetails with the more culturally attuned assessment of political geographer Peter Taylor who argues that "cities are replacing states in the construction of social identities." Cities like São Paulo and Shanghai, Lagos and Bombay, are likely to challenge the more traditional urban centers, not just in size - they have already done that but, primarily as leading incubators in the global economy, progenitors of new urban form, process and identity. They are already cities in which the journey to work has become excessive for many people without obviously challenging the law of value. Thus just as the intense research and policy focus on cities in the 1960s and 1970s quickly gave way to a preoccupation with regional change in recognition of the new industrial regionalism of the late twentieth century economy, this regional worldview is now itself outdated and will give way in the twenty first century to a metropolitan cum planetary outlook, local cum global. Significant signs of this are already apparent. Rare was the city in 1975 that had its own trade missions but a quarter century later it is the rare city that does not. And in New York the fin de siècle mayor, Rudy Giuliani, piqued at the mounting parking chaos combined with diplomatic immunity resulting from the presence in his city of the United Nations, and just as piqued at the US government's refusal to tackle the problem, threatened only half in jest that New York City would begin adopting its own foreign policy. No-one seriously argues that the twenty first century will see a return to a world of city-states but it will see a recapture of urban political prerogative vis-à-vis nation states.

\section{The New Geography of Uneven Development}

The long twentieth century was the century of uneven development, spurred on by the unprecedented accumulation and mobility of capital, it became so just as surely via certain strategic fixations of càpital, in specific scales matched to specific functions in the global landscape. The question of contemporary uneven development has so far been posed here in rather dichotomous terms: equalization vis-a-vis differentiation; powerful globalized control centers of the world with

25) Taylor, P., 'World cities and territorial states: the rise and fall of their mutuality', (Knox, P. and Taylor, P., eds., World cities in a world system, Cambridge University Press, 1995), p.158. 
the geographies of powerlessness and expulsion. This vision is real enough as far as it goes. I stress it here because I think that for more than a decade, the search for a politics of global affairs, at least in the Euro-American left has focused on cultural, discursive and social fault lines of "difference" at the expense of economic analysis. I have not dug into the highly gendered contours of global restructuring nor for that matter the class restructuring that is afoot. Nor indeed have I looked at the dramatic reinscription of race that has accompanied economic privatization, the elevation of Islam to global enemy number one, large scale Asian migrations, or the end of the cold war. And what of the re-posing of environmental crises at a global scale, and the dramatic co-option of environmental politics by corporate capital and the state: environmentalism in the US has become a conduit for capital accumulation.

With his adamant argument that capitalism brought about an "annihilation of space by time," Marx emphasized the equalization of conditions and levels of development brought about by capital rather than geographical differentiation. Rosa Luxemburg took this argument to its logical conclusion, suggesting that when the capitalization of the globe was geographically complete, capitalism would be economically and socially complete, and necessarily would flounder. But this line of argument is intrinsically too crude and in the end unhelpful. In the first place, Marx's vision of globalization was largely restricted to the sense of a world market in commodities. First and foremost, Marx expected that what he called the "backward" countries would be integrated into the world economy primarily as markets for capitalist manufactures. This would require that the reservoir of new global consumers have access to higher amounts of income, implying higher wages, for otherwise the imported manufactures would not be affordable: equalization would be led by marketization. Obviously this is not the path that "the development of underdevelopment" took. Marx severely underestimated the economic power of political-territorial boundaries, and the differentiation of wage rates that could be enforced - either politically or via the market between nation-states. For rather than a reservoir of consumers, the underdeveloped world has, in the last century, been rendered more a reservoir of cheap labor (used only fittfully until the 1970s) thus thoroughly contradicting Marx's expectations.

Put differently, the current fluid pattern of uneven development represents an always fleeting spatial solution to an inherent economic contradiction in the social relations of capital. Amidst all the current talk of global markets, it has to be remembered that the expansion of capital in general and of individual capitals in particular is ultimately dependent on finding an expanded labor force, technological developments notwithstanding, and it is this more even than the search for markets that has directed uneven development in the last two decades: the industrialization of various erstwhile "Third World" economies has been dramatic. As a solution to the problem of labor, numerous underdeveloped economies have been begrudgingly invited into conditional citizenship within the compound of global capital, even as the walls of the compound have been raised higher. At the same time, the level of global migration to established centres of production is unprecedented, even as the proliferation of so-called "underclasses" in these same centers bespeak

26) (1) Luxemburg, R., The accumulation of capitalism, New York Monthly Review Press, 1968, 289p. See also (2) Warren, B., Imperialism. pioneer of capitalism, Verso, 1980, 274p. 
the local satanic geographies of the core. The social and political conflict thus staged was clear for everyone to see in the streets of South Central Los Angeles during what Mike Davis describes as "the first multicultural uprising in recent American history." The resolution of the central dialectic of uneven development - the joust between processes of equalization and differentiation - is thereby rendered even more intensely geographical: as a symptom of globalization, geoeconomic turf wars emerge at everything from the global to the local scale.

In the period from the 1880s to the end of World War I a fundamental transition took place in the global production of space. Contrary to Rosa Luxemburg's (and Marx's) expectations, the conjuncture of economic and geographical expansion, which had characterized European-centered global capitalism, was dismantled. Figures as diverse as Vladimir Lenin and Cecil Rhodes, and the geographers Isaiah Bowman, Halford Mackinder and Alexander Supan, all understood in different ways that with the world completely divided between discrete "modern" nation-states (and their colonies), economic expansion ceased to be tied so directly to territory. Absolute economic expansion would henceforth involve relative geographical expansion of one place vis-a-vis another - the constant division and redivision of the world - rather than an absolute geographical expansion. From this period onward, the unevenness of capitalist development was driven less by the difference between capitalist economies and the "backward" (that is, pre-capitalist) societies that lay outside the global market, than by the unevenness inherent in the logics of capital accumulation.

Against the backdrop of this distinct economic geography of the twentieth century, how are we to conceive of the still incomplete transition the apparent stability of postwar Fordism? In the first place, it has to be remembered that the US-led globalism of the middle of the century was always incomplete. The Russian revolution, the Stalinist regimes of eastern Europe following 1945, and the Chinese revolution severely circumscribed (but did not entirely cut off) access by capital to these places and populations. With all of these economies now scrambling for access to the global market, the current restructuring is taking place under an expanded set of geoeconomic conditions. The significant industrialization of many economies in Asia and Latin America, the entry of China into the global market after 1979, and the aggressive attempts to capitalize the Soviet and East European economies since 1989 do not fundamentally alter the central dialectic of uneven development so much as take it to its limit. The dilemma of labor power vis-a-vis capital is represented afresh: the flow of capital to economic spaces of least resistance where initially low labor costs lubricated partial integration of the NICs into the central circuits of the global economy has in turn created reciprocal pressure to increase wages in those same economies, either from workers' demands and organization (for instance, in South Korea or Brazil) or from further competition from never, even lower-wage NICs building niches in the global market. Thus since the mid 1980s, these earliest NICs have themselves been undercut and are no longer the choicest locations when cheap labour is the primary consideration. Singapore, Taiwan, Hong Kong and South Korea now increasingly lose out to the intense competition from lower wage Asian neighbors such as Malaysia and Thailand, and at the same time they exploit these economies for ancillary production in electronics, textiles and other industrial sectors. Now, however, unlike earlier periods of expansion,

27) Katz, C. and Smith N., 'LA intifada: interview with Mike Davis', Social Text 33, 1992, pp.19-33. 
Russia, China, Eastern Europe and the ex-Soviet Republics are available for capitalization. If expansion of the global economy again requires the colonization of cheap-labor economies, as it did with the NICs after the 1960s, the choice of locations has dramatically expanded. The contradiction of equalization and differentiation is not so much resolved as displaced - literally - to be reposed else where.

This expansion of the global space of capital is bad news for much of Africa and for many communities in Asia and Latin America. In the first place it makes the redlining of Africa even more feasible. J. Brian Atwood, the administrator for USAID continues to exude the evolutionary optimism of modernization theory: "Africa is today what Latin American and Asian markets were a decade ago. It is the last great developing market." But elsewhere in the global economy, the reality of African redlining is sufficiently understood that selective "Africanization" is a looming specter for even relatively prosperous Asian and Latin American economies fighting to displace devaluation and disinvestment elsewhere. It was, for example, barely under the surface in Mexican debates over NAFTA. For more enlightened Mexican capitalists, the prospect of NAFTA was not simply that the trade agreement would attract massive capital investment from the North and open up Canadian and US markets. They anticipated that NAFTA would also increase Mexican wages, albeit following rather than leading price and productivity increases, thus Mexican market. The 1995 devaluation of the peso brought a hard global disciplining of Mexican wages "Africanization" is nowhere more feared than in Mexico - but the continuance of NAFTA could well put significant upward pressure on wages in some sectors of the Mexican economy. Meanwhile, opponents led by the Zapatistas, understood two things: first, any wage increases would be at best sectoral with comparatively little trickle down to the Chiapas peasantry. Second, and this is crucial, unlike East Asia, Mexico would already have privileged access to the massive market of North America, and Mexican capitalists would have a diminished incentive to increase wages and thereby create a domestic market at home. In this light, the prospects for Mexico seem rather stark: either low wages are maintained, through repressive means if necessary, or else partial prosperity in Mexico will be matched by a wholesale geographical shift of the Maquilladora zone to the Guatemalan border, the new southern border of the capitalist core. Either way, the Mexican state, for most of the twentieth century the exclusive property of the Partido Revolutionar Institutional (PRI) is now dramatically weakened at the hands both of globalization and its opponents.

But it is not just in Mexico that the expansion of global labor markets into the erstwhile Soviet block is bad news. In South central LA or Belleville in northern Paris or the Portuguese countryside, increasingly globalized labor markets threaten to "Africanize" local economies and communities in a way that would have been unprecedented as late as the 1970s. With wage competition increasingly transnational and state welfare provisions eroded, the global economy is ever more efficient at writing off redundant spaces of accumulation: the flexibility of investment and market options is matched by a wholly new flexibility in disinvestment and abandonment.

Apart from anything else, then, the current phase of global expansion is characterized by an

28) Quoted in French, op. cit. 
unprecedented geographical disjuncture between production and consumption, between work and the market. As late as the 1970s, the industrialization of the NICs could be assumed to bring with it an expanded domestic market. The development of Taiwanese production would have been inconceivable without the parallel development of a large consumer market for many of the commodities being produced. Today, however, the development of markets can be more successfully (if never completely) separated from the development of production making host economies uniquely vulnerable to "globalization."

At the global scale, East and South East Asia and Latin America currently straddle the cusp of this contradiction between equalization and differentiation in the global economy. There are many examples of national and local economies being hitched to global capital and of others being effectively ditched. None is entirely excluded from the global economy, of course, but many places and people have so far proven to be flexibly replaceable. This results in what I have elsewhere described as "the satanic geographies" of globalization and uneven development. Its central hallmark is a striking spatialization of the class and race, gender and national relations that make global production as a social process.

If Arrighi is right to identify anew regime of capital accumulation, we can add that this new regime is built on the twin geographies of fundamental local and global restructuring. Caught in the middle is the nation state. The erosion of national state power in economic terms is indisputable in the global economy of the twenty-first century, but it is far from an even process. Whereas some states - the US for example - are via the power of their economies in a position to manipulate the global economy to their own interests (if not in any way control that economy), other economies, such as Indonesia, find themselves with little power to manipulate the global market, leaving them little more than the possibility of raising major barriers to global penetration.

This rescaling economic flows at the global level and political responses from nation states, therefore remake the state as a target of political resistance. The selective weakening of the national state provides opportunities for sub-state and supra-state empowerment. In other cases, the coalition of a national state with neo-liberal globalism makes them equally vulnerable to attack on more nationalist grounds. This has been the case most obviously in Mexico where Salinas and Zedillo allegiances to a global economic agenda - via the IMF/US imposed 1994 structural adjustment and adherence to NAFTA - have made the ruling class PRI more vulnerable than at any time in its history, and have directly provoked the Zapatista and related uprisings. In a quite different way, the same vulnerability led to the downfall of the Suharto regime in Indonesia. Slobodan Milosevic chose to harness nationalist reaction against a similar fate. Others will follow.

As Rosa Luxemburg's example suggests, there are no geographical limits to capitalist expansion. Or at least, any such planetary limits are very far from being confronted and will be rendered moot by extra-planetary economic expansion, already well underway thanks to NASA. Rather, it is the internal geography of capitalist unevenness that makes economic stability so vulnerable. In the organized and disorganized political assaults against nation states that have exploited and repressed their citizens - states which now find themselves suddenly vulnerable - it is vital that we remember the flexibility of the new global geography of uneven development and that the limits on simply national assaults on power are kept clearly in mind. 


\title{
The Restructuring of Spatial Scale and the New Global Geography of Uneven Development
}

\author{
Neil SMITH \\ Department of Anthropology, Graduate Center, CUNY, U.S.A.
}

The widespread recognition of globalization in the 1980s and 1990s has encouraged the belief that geographical space is less relevant to the progress of capital accumulation. Contrary to many official accounts, globalization is not stimulated by the internationalization of finance capital so much as by the internationalization of production capital. Beneath globalization, a much more comprehensive process is taking place - a thoroughgoing restructuring of geographical scale. This paper argues that capital accumulation has entered a new stage in which, with the relative demotion of the nation-state in economic terms, the global-local nexus is increasingly definitive. This in turn leads to a new pattern of uneven geographical development in which a number of Asian and Latin American economies have been conditionally integrated into the core of global capital while Africa and marginalized populations throughout the world are increasingly excluded from it.

Key words: globalization, geographical scale, uneven development, new world order

\section{空間スケールの再構築と不均等発展の新しいグローバルな地理 \\ ネイール・スミス \\ アメリカ合衆国・ニューヨーク市立大学・人類学科}

1980年代と 1990年代のグローバル化に関する広く行きわたった認識は、資本蓄積の進行に 地理的空間がますます関わらなくなっているという考えを助長してきた。多くの公式的な見解 とは反して、グローバル化は金融資本の国際化よりも製造資本の国際化に刺激を受けている。 グローバル化のもとでは、はるかにより包括的な過程が生じている——それは徹底的な地理的 スケールの再構築である。本稿は、資本蓄積が、経済的な状況については国民国家の相対的後 退を伴いつつ、グローバルーローカル関係がますます決定的になる新たな段階に突入している ことを論じる。このことにより、グローバルな資本の中核に多くのアジアとラテンアメリカの 経済が状況に応じて統合される一方でアフリカと世界中の縁辺化された人々がますます追い払 われる、地理的不均等発展の新しいパターンがあらわれている。

チーワード：グローバル化, 地理的スケール, 不均等発展, 新世界秩序 